\title{
A New Species of Scytalidium Pesante on Diospyros melanoxylon Roxb. from Central India
}

\author{
Neha Awasthi ${ }^{1 *}$,Anurag Dubey ${ }^{2}$, Smriti Bhardwaj $^{2}$ and Akhilanand Rai ${ }^{2}$ \\ ${ }^{\prime}$ Dept. of Botany, Govt. Naveen College, Nowgong, Chhatarpur,MP, India \\ ${ }^{2}$ Laboratory of Mycotaxonomy, Dept. of Botany, School of Biological Sciences, Dr. Harisingh Gour Central University, Sagar, MP, India. \\ "Corresponding authorEmail: nehamycology@gmail.com
}

(Submitted on June 20, 2020; Accepted on October 12, 2020)

\begin{abstract}
During the mycological survey of Garhpehra forest, Sagar, MP, India, a new species of Scytalidium Pesante was encountered on Diospyros melanoxylon Roxb. The material was subsequently worked out, described, illustrated and identified. After a thorough survey of literature, it was found to be a novel species of Scytalidium which have been named as Scytalidium melanoxylicola sp. nov. Photomicrographs and camera lucida drawings of the investigated fungus has also been provided.
\end{abstract}

Keywords: Arthrospores, Chlamydospores, Scytalidium, trichomes

\section{INTRODUCTION}

The genus Scytalidium Pesante belongs to dematiacious hyphomycetes. Till date only thirty six species are recorded under this genus (http//:www.indexfungorum.org). The genus was established by Pesante in 1957 with its type species as Scytalidium lignicola (Ellis, 1971). The type species was first isolated from rotten wood of Platanus (Holubova-Jechova, 1990) and further reported to cause subcutaneous phaehyphomycosis in humans (Dickinson et al., 1983). The genus Scytalidium is characterized by the presence of intercalary or terminal arthrospores and chlamydospores (Ellis, 1971; Sigler and Carmichael, 1976). This fungal genus is quite common on diverse range of substrates, such as soil, plant parts, animals, and on other fungal members (Klingstrom and Beyer,1965; Ellis, 1971; Rao and Hoog, 1975; Soni et al., 1989; Kang et al., 2010; Dubey and Pandey, 2011; Gautam et al., 2015). It has been noticed that species of Scytalidium isolated from soil and certain plants hosts e.g. Pinus and Platanus are capable to cause severe problems in animals and human beings. Scytalidium multiseptatum isolated from soil was also reported to be present in Potato cyst nematode Globodera rostochiensis (Holubova-Jacova, 1990). S. dimidiatum is a thermotolerent plant pathogen reported to cause chronic cutaneous infections in human beings (Hay,2002; Hay and Moore,1984; MorrisJones et al., 2004; Lacaz, 1999; Oyekaand Okoli, 2003) while some are also responsible for bronchial infections in cattles (Udagawa, et al., 1986) S.aurantiacum (isolated from Pinus sylvestris and Betula alba) and Scytalidium album (isolated from Picea abies) also showed antagonistic activity to other fungal members (Klingstrom and Beyer, 1965). The presence on a wide range of substrates and potential to cause severe infections in humans e.g. onycomycosis, phaeohyphomycosis, mycetoma, subcutaneous abscesses, fungemia, endophthalmitis and bronchial infections in cattles make it worthy of investigation.

Present communication deals with the taxonomic description and illustration of a novel species of Scytalidium present on living leaves and leaf trichomes of Diospyros melanoxylon Roxb. During the survey of field mycology from South Sagar Forest Division, Madhya Pradesh, India. The comparison of the taxonomic features of the proposed fungus with available literature on allied taxa revealed it to be a novel species of Scytalidium, namely $S$. melanoxylicola $\mathrm{sp}$. nov. described and illustrated here in this paper.

\section{MATERIALAND METHODS}

Macro-and Microscopic observations: Specimens with distinct fungal propagules on living leaves of Diospyros were collected from Garhpehra forest, Sagar, M.P. India and carried to the laboratory for further processes following standard protocols. Pictures of infection spots were captured using a Sony DSC-X80 camera. Free-hand cut sections and scrap mounts were prepared in clear lacto-phenol cotton blue mixture morphomycotaxonomic observations. Microscopic observations were taken with Leica light microscope. Camera lucida drawings were prepared using Nikken Tokyo camera lucida at different magnifications of a compound light microscope. The measurements of mycelium, arthroconidia, and chlamydospores (with the extremes given in parentheses) were done with the help of ocular micrometer. The holotype was deposited in Ajrekar Mycological Herbarium (AMH), Agharkar Research Institute (ARI), Pune, India and an isotype was retained in the mycological herbarium of the Department of Botany of Dr. Harisingh Gour University (MH-DHSGU), Sagar, M.P., India. The identity of the newly described taxon was verified using relevant literature (Dubey and Pandey, 2011; Ellis, 1971; Holubova- Jacova, 1990; Rao and Hoog, 1975).

\section{TAXONOMIC DESCRIPTION}

Scytalidium melanoxylicola N. Awasthi, A. Dubey, S. Bhardwaj and A.N. Rai sp.nov.

(Fig. 1-4)

\section{MycoBank no.: Mb835460}

Diagnosis: Proposed species of Scytalidium differs from other allied species in having branched superficial and septate mycelium which is documented climbing around and sometimes present inside the lumen of trichomes, and the presence of spherical to ellipsoidal, thick walled broad arthroconidia and with highly thick walled chlamydospores.

Etymology: The species epithet is derived from the name of the host species.

Description: Leaf spots amphigenous, sub circular to irregular, dark black. Colonies effuse, hypophyllous, dark black, localized, velvety. Mycelium branched superficial, brown to dark brown, septate, 4-6 $4 \mathrm{~m}$, creeping and climbing around trichomes, sometimes present inside the lumen of the trichomes, mid brown to dark brown, thick-walled, smooth, 


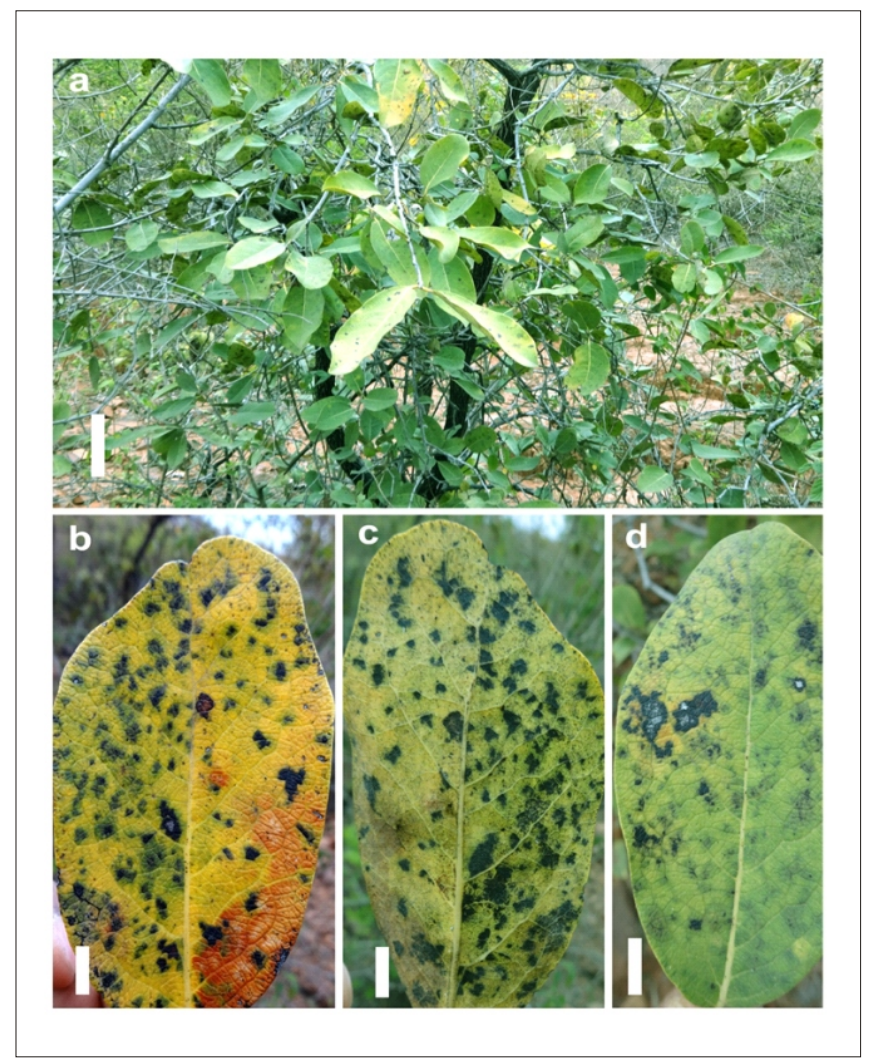

Fig. 1: Symptoms of Scytalidium melanoxylicola on Diospyros melanoxylon (Holotype AMH 9682). a. Infected host plant; b-d. Infection spots on upper and lower surface. Scale bars: a-d. $10 \mathrm{~mm}$

septate, branched, fragmented to form arthroconidia which are dark brown, thick-walled, spherical to ellipsoidal, smooth, with branched catenation, 0-1(-3)septate, septa thick-walled, 12-15 × 13-16 $\mu \mathrm{m}$, sometimes intercalary cells form chlamydospores (resting spores) which are circular to oval, very thick-walled, smooth, brown to dark brown, 24-28 $\times 26-32 \mu \mathrm{m}$

Type: On living leaves of Diospyros melanoxylon Roxb. (Ebenaceae), Garhpahra forest, South Sagar Forest Division, DHSGU, Sagar, M.P., India, March 2015, leg. N. Awasthi, (Holotype AMH 9682, Isotype MH-DHSGU 8).

\section{DISCUSSION}

The presently described species of Scytalidium is morphologically quite different from the other known species of the genus. A literature survey and the available information in Mycobank database (http://www.mycobank.org) and Index fungorum (http://www.indexfungorum.org) exhibited that only a limited number of species of Scytalidium are reported on a variety of hosts and substrates. However, very few species are reported from plants. Literature survey also revealed that no species of Scytalidium has ever been reported on Diospiros melanoxylon. However, two species of Scytalidium, viz. S. terminale Rao \& Hoogand, S. zapotae Dubey \& Pandey (Dubey and Pandey, 2011; Rao and Hoog, 1975) are reported on the plant hosts belonging to order Ebenales. The presently described species is quite close to $S$.

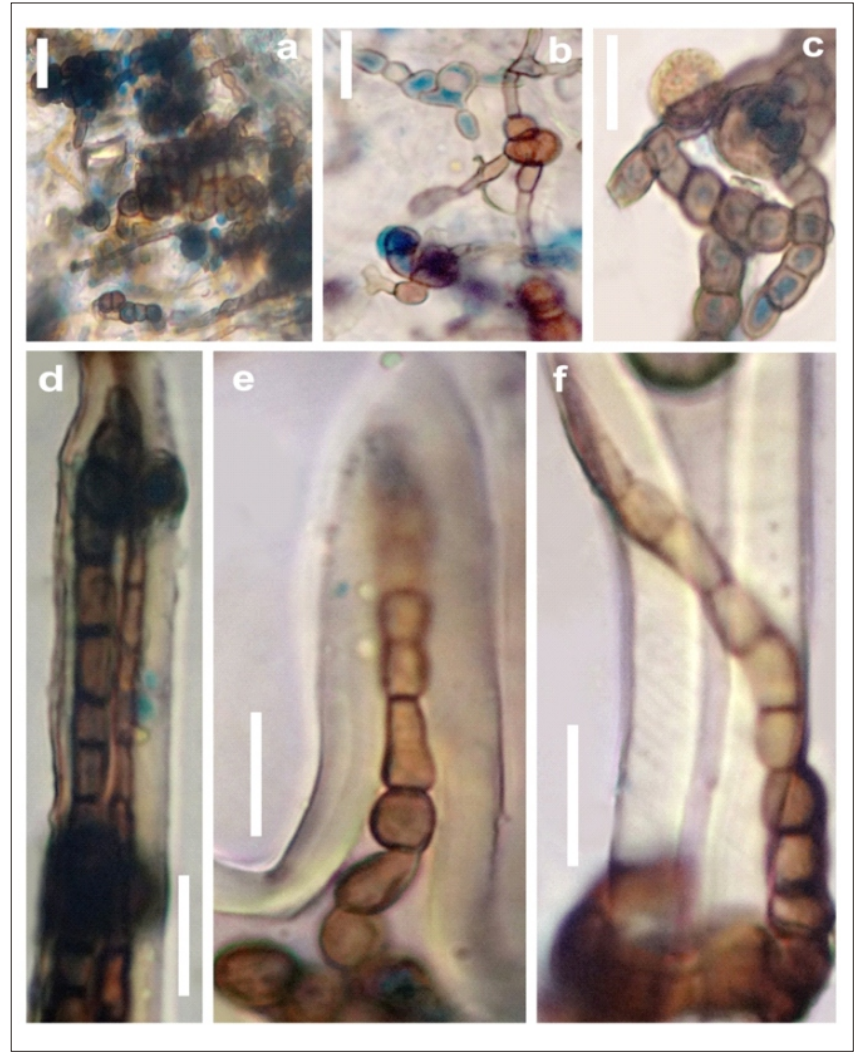

Fig. 2: Scytalidium melanoxylicola, photomicrographs (Holotype AMH 9682). a-c. Superficial hyphae; d-e. Hyphae inside lumen of trichomes; f. Creeping hyphae surrounding trichome. Scale bars: a-f $10 \mu \mathrm{m}$

terminale with which it has been compared (Table 1). The presently described species is quite different from the allied species in having branched superficial, brown to dark brown, septate mycelium which can be noticed creeping and climbing around trichomes and sometimes present inside the lumen of trichomes which is not the case in $S$. terminale. The newly proposed species also differs in having spherical to

Table 1: Comparison of Scytalidium melanoxylicola sp. nov. with S.terminale.

\begin{tabular}{|l|l|l|}
\hline Character & $\begin{array}{l}\text { Scytalidium terminale Rao } \\
\text { \& Hoog (Rao and de } \\
\text { Hoog, 1975) }\end{array}$ & $\begin{array}{l}\text { Scytalidium melanoxylicola } \\
\text { sp. nov. }\end{array}$ \\
\hline Mycelium & $\begin{array}{l}\text { Mainly submerged, hyphae } \\
\text { smooth-and thin walled, } \\
\text { hyaline to subhyaline, 1.5 } \\
3 \mu \mathrm{m} \text { wide. }\end{array}$ & $\begin{array}{l}\text { Branched superficial, brown } \\
\text { to dark brown, septate, 4-6 } \\
\mu \mathrm{m}, \text { creeping and climbing } \\
\text { around trichomes and } \\
\text { sometimes present inside the } \\
\text { lumen of trichomes. }\end{array}$ \\
\hline Arthroconidia & $\begin{array}{l}\text { Single or in chains, } \\
\text { rectangular, smooth and } \\
\text { thin walled, concolorous } \\
\text { with the hyphae, } \\
\text { sometimes slightly } \\
\text { swollen, usually 10-20 x 2- } \\
3 \mu \mathrm{m} .\end{array}$ & $\begin{array}{l}\text { Catenate, spherical to } \\
\text { ellipsoidal, smooth, thick } \\
\text { walled, dark brown, 0-1(-3)- } \\
\text { septate, septa thick -walled, } \\
12-15 \times 13-16 \mu \mathrm{m} .\end{array}$ \\
\hline Chlamydospores & $\begin{array}{l}\text { Single, occasionally in } \\
\text { short chains, obovoidal, } \\
\text { ellipsoidal or pyriform, } \\
\text { smooth and thick walled, } \\
\text { pale to dark brown, } \\
\text { obovoidal, ellipsoidal or } \\
\text { pyriform, usually 15 -25 x } \\
7-9 \mu \mathrm{m} .\end{array}$ & $\begin{array}{l}\text { Circular to oval, smooth, } \\
\text { very thick }- \text { walled, brown to } \\
\text { dark brown, 24 -28 } \times 26-32 \\
\mu \mathrm{m} .\end{array}$ \\
\hline
\end{tabular}




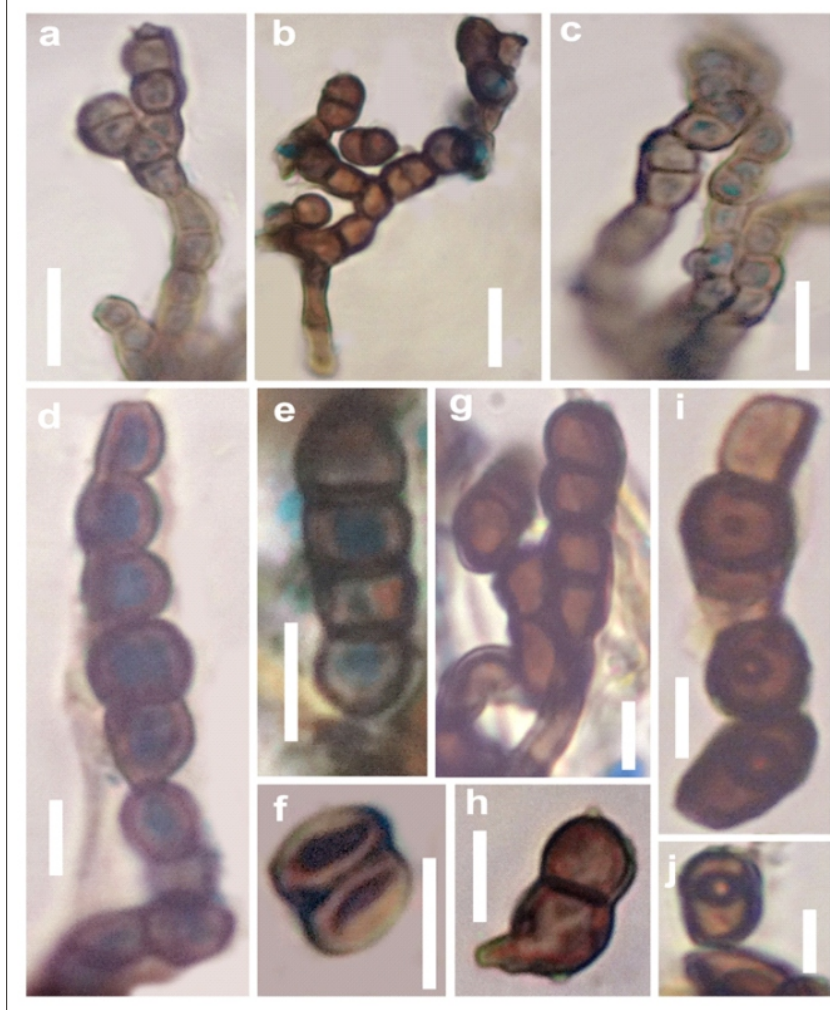

Fig. 3: Scytalidium melanoxylicola, photomicrographs (Holotype AMH 9682). a-g. Arthroconidia; h. Germinating arthroconidia; i-j. Chlamydospores. Scale bars: a-c. 10 $\mu \mathrm{m}, \mathbf{d}-\mathbf{j} .5 \mu \mathrm{m}$

ellipsoidal, thick walled and broader arthroconidia. The presence of very thick walled and broader chlamydospores in the proposed species is yet another key feature using which a noval species has been described.

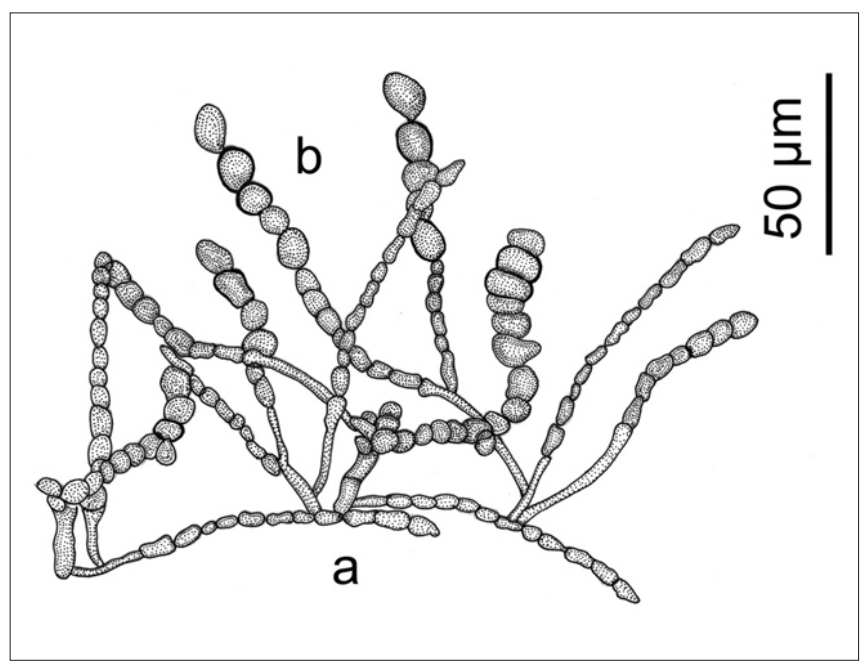

Fig. 4: Scytalidium melanoxylicola, Camera lucida drawings (Holotype AMH 9682). a. Creeping superfecial mycelium; b. Spores (Arthroconidia and Chlamydospores). Scale bar: Scale bar: $50 \mu \mathrm{m}$.

\section{ACKNOWLEDGEMENTS}

We are thankful to the Head, Department of Botany, School of Biological Sciences, Dr. Harisingh Gour Central University, Sagar and Principal, Govt. Naveen College, Nowgong for providing laboratory facilities and to Curator, Ajrekar Mycological Herbarium (AMH), Agharkar Research Institute, Pune for accepting the fungal specimen and providing the accession number. Thanks are also due to the MycoBank team for nomenclatural corrections. This work was financially supported by UGC, Govt. of India.

\section{REFERENCES}

Dickinson, G.M., Cleary, T.J., Sanderson, T. and McGinnis, M. R. 1983. First case of subcutaneous Phaeohyphomycosis caused by Sctalidium lignicola in a human. Journal of Clinical Microbiology 17(1): 155-158.

Dubey, R. and Pandey, A. K. 2011. New Species of Scytalidium Pesante and Sporidesmium Link ex Fries from India. Nelumbo 53: 1-6.

Ellis, M.B. 1971. Dematiaceous Hyphomycetes. Commonwealth Mycological Institute: Kew, Surrey, UK.608p.

Gautam, A. K., Avasthi, S. and Bhadauria, R. 2015. A new species of Scytalidium from Himachal Pradesh, India. J. New Biol. Rep. 4: 7-10.

Hay, R. J. 2002. Scytalidium infections. Curr. Opin. Infect. Dis.15: 99-100.

Hay, R. J., and Moore M. K. 1984. Clinical features of superficial fungal infections caused by Hendersonula toruloidea and Scytalidium hyalinum. Br. J. Dermatol. 110: 677-683.

Holubova-Jechova, V. 1990. A new species of Scytalidium isolated from cysts of Globoderarosto chiensis in Czech Republic. Ceska Mykologie 44(2): 101-105.

Kang, H. J., Sigler, L., Lee, J., Gibas, C. F. C., Yun, S. H. and Lee, Y. W. 2010. Xylogone ganodermophthora sp. nov., an ascomycetous pathogen causing yellow rot on cultivated mushroom Ganoderma lucidum in Korea. Mycologia 102: 1167-1184.

Klingstrom, A., and Beyer, L. 1965. Two new species of Scytalidium with antagonistic properties to Fomes annosus (Fr.) Cke. Svensk Botanisk Tidskrift 59: 30 6.

Lacaz, C. S., Pereira A. D., E., Heins-Vaccari E. M., Cuce L.C., Benatti R. C.and Nunes S. 1999. Onychomycosis caused by Scytalidium dimidiatum. Report of two cases. Review of taxonomy of the synanamorph and anamorph forms of the coelomycete. Rev. Inst. Med. Trop. Sao Paulo 41: 319-323.

Morris-Jones, R., Youngchim, S., Hextall, J. M., Gomez, B. L., Morris-Jones, S. D., Hay, R. J., Casadevall, A., Nosanchuk, J. D. and Hamilton, A. J. 2004. 
Scytalidium dimidiatum causing recalcitrant subcutaneous lesions produces melanin. J. Clin. Microbiol. 42: 3789-3794.

Oyeka, C. A. and Okoli, I. 2003. Isolation of dermatophytes and non-dermatophytic fungi from soil in Nigeria. Mycoses 46: 318-320.

Rao, V. and de Hoog, G. S. 1975. Some notes on Torula. Persoonia-Molecular Phylogeny and Evolution of Fungi 8: 199-206.
Sigler, L. and Carmichael, J.W. 1976 Taxonomy of Malbranchea and some other hyphomycetes with arthroconidia. Mycotaxon 4: 349-488.

Soni, K.K., Jamaluddin and Rajak R.C. 1989. A new species of Scytalidium from India. Curr. Sci. 58: 16.

Udagawa, S., Tominaga, K. and Hamaoka, T. 1986. Scytalidium japonicum, A new species, the causal agent of Cattle Bronchiolitis. Mycotaxon 5: 279-286. 